granting of services is less likely to be detected than the granting of price differentials. ${ }^{59}$

In addition, the furnishing of services may in some circumstances be more appropriate than a price differential to pass on cost savings to a buyer. The furnishing of a "demonstrator" to the buyer, ${ }^{60}$ for example, would result in a benefit to the seller ${ }^{61}$ while at the same time providing a means of returning to the buyer the amount justified by cost savings. In any event, advertence to the fact of cost savings at the time a differential is granted does not appear to be a requirement for cost justification under Section 2(a) ${ }^{62}$ Thus prohibition of cost-justified, though disproportional, differentials in services or payments for services would disadvantage the seller with actual cost savings, and would therefore result in "disparity in the statutory consequences which attach to economically equivalent business practices." 63

${ }^{59}$ Although a payment for services, dealt with in Section 2(d), might be hidden from the public, no reason appears why the granting of a price differential could be more easily discovered.

${ }^{80} \mathrm{~A}$ "demonstrator" is a salesman whose services are furnished by the seller to the buyer. The "demonstrator" will perform the normal salesman's duties at the buyer's place of business, but will also take every opportunity to call the attention of the buyer's customers to the seller's product. See Elizabeth Arden, Inc. v. Gus Blass Co., 150 F.2d 988 (C.A.8th, 1945), cert. denied 326 U.S. 773 (1945). Thus, of two equal expenditures, that for providing services to the buyer may be of more benefit to the seller than would the granting of a price differential to the buyer.

${ }^{61}$ See discussion in the preceding note.

62 Although the furnishing of services has been said not to be on "proportionally equal" terms unless furnished according to a standard or program set up at the time the services were granted [see Elizabeth Arden, Inc. v. Gus Blass Co., 150 F.2d 988 (C.A.8th, 1945)], no similar holding with respect to cost justification has been found.

${ }^{63}$ Attorney General's Report 191 (1955).

\title{
ACCORDING FULI FAITH AND CREDIT TO FOREIGN MODIFIABLE ALIMONY DECREES
}

Limited recognition and enforcement of foreign modifiable alimony decrees often result in serious prejudice to a wife's $(W)^{1}$ right to installment payments where the husband $(\mathrm{H})$ has left the jurisdiction rendering the decree. ${ }^{2}$ Because the Full Faith and Credit Clause ${ }^{3}$ has been held to compel recognition only in

${ }^{1}$ For ease of reference, husband and wife will be designated by the symbols $H$ and $W$ respectively. The state awarding the alimony decree will be designated as F-1; the state in which enforcement of the decree is sought will be designated as F-2. "Foreign," as used in this Comment refers to sister states rather than foreign countries, and "alimony" includes support and separate maintainance.

2 See Jacobs, The Enforcement of Foreign Decrees for Alimony, 6 Law \& Contemp. Prob. 250 (1939).

${ }^{3}$ U.S. Const. Art. $4, \$ 1$. 
the case of non-modifiable accrued installments, ${ }^{4}$ modifiable arrearages and future installments have usually been denied recognition. But in Light v. Light, the Illinois Supreme Court held that a Missouri alimony decree was entitled to full faith and credit with respect both to unpaid accrued installments and to modifiable future installments. ${ }^{6}$ This result may have far-reaching implications with respect to recognition and enforcement of accrued installments, recognition and enforcement of future installments, and foreign modification-the three problems which have frequently plagued the courts when dealing with foreign alimony decrees. ${ }^{7}$

\section{I}

The problem of recognition of accrued installments under a foreign decree first came before the Supreme Court of the United States in Barber v. Barber. ${ }^{8}$ In allowing recovery of unpaid arrearages the Court seemed to be of the view that full faith and credit must be given to accrued installments of foreign alimony decrees on a broad basis. ${ }^{9}$ But in Lynde v. Lynde ${ }^{10}$ this broad view was sharply curtailed. The Court held that full faith and credit did not compel recognition of retrospectively modifiable accruals which had not been reduced to a final judgment for a fixed sum. As no mention of the Barber case was made in the

4 Sistare v. Sistare, 218 U.S. 1 (1909).

5 12 Ill.2d 502, 147 N.E.2d 34 (1958).

${ }^{6} \mathrm{~W}$ sought registration of the Missouri decree under the Uniform Enforcement of Foreign Judgments Act, which applies only to such judgments and decrees as are entitled to full faith and credit. Ill. Rev. Stat. (1957) c. 77, \$88(a). The circuit court had entered a decree directing that the Missouri decree be registered as to accrued installments. $H$ appealed the registration, and $W$ cross-appealed due to the court's failure to register the future installments.

7 Due to the availability of the registration procedure, the effect of the Light case may be strongest in the other states which have adopted the Uniform Enforcement of Foreign Judgments Act. Ark. Stat. Ann. (Supp., 1957) \$\$29-801 to 29-818; 32 Mo. Stat. Ann. (Vernon, 1952) $\$ 511.760 ; 2$ Neb. Rev. Stat. Ann. (1956) $\$ \$ 25-1587$ to $25-15,104 ; 1$ Ore. Rev. Stat. (1957) $\$ \$ 24.010-24.180 ; 1$ Rev. Code of Wash. (1956) c. 6.36; 33 Wis. Stat. Ann. (1958) $\$ 270.96 ; 1$ Wyo. Comp. Stat. (Supp., 1957) c. 3 Art. 80.

821 How. (U.S.) 582 (1858). In an equity proceeding in the United States District Court for Wisconsin, W sought to compel payment of accrued installments under a New York alimony decree. The relief was granted, and the Supreme Court affirmed, holding that diversity jurisdiction was proper as $\mathrm{W}$ had a separate domicile from $\mathrm{H}$ due to the divorce $a$ mensa et thoro.

9 "The decree ... is a judgment of record, and will be received as such by other courts. And such a judgment or decree, rendered in any State in the United States, the court having jurisdiction, will be carried into judgment in any other State, to have there the same binding force that it has in the State in which it was originally given." Id., at 591.

10181 U.S. 183 (1901). The action was brought in New York to enforce a New Jersey decree. W sought to compel payment of decreed accruals, and of installments accrued subsequent to the decree. She also requested equitable enforcement of prospective installments. The Special Term decreed full recovery and prospective enforcement, but the Appellate Division held that W was entitled only to an action at law for the decreed accruals. 41 App. Div. 280, 58 N.Y. Supp. 567 (1899), aff'd 162 N.Y. 405, 56 N.E. 979 (1900). The Supreme Court affirmed on the ground that full faith and credit did not compel recognition or enforcement. 
Iynde opinion, it was not apparent whether the latter overruled, qualified, or merely stood in conflict with the former.

This situation was clarified by the Supreme Court in Sistare v. Sistare. ${ }^{11} \mathrm{Mr}$. Justice White stated the test for full faith and credit:

[W] here a decree is rendered for alimony and is made payable in future installments the right to such installments becomes absolute and vested upon becoming due, and is therefore protected by the full faith and credit clause, provided no modification of the decree has been made prior to the maturity of the installments. ${ }^{12}$... This general rule, however, does not obtain where by the law of the State in which the judgment for future alimony is rendered the right to demand and receive such future alimony is discretionary with the court which rendered the decree. ... ${ }^{13}$

The Court held that the New York decree in question was not retrospectively modifiable,$^{14}$ and, thus, the Connecticut court was compelled to recognize accruals under it.

The Sistare case stands for the proposition that full faith and credit requires F-2 to recognize installments accrued under an F-1 decree unless the accruals are subject to retrospective modification in F-1.5 This proposition rests on the assumption that finality is requisite to full faith and credit. ${ }^{16}$ The practical result of the finality requirement is that $W$ may find herself unable to enforce a retrospectively modifiable decree, if $\mathrm{H}$ has left the jurisdiction and has no assets

11218 U.S. 1 (1909). W brought an action in Connecticut to recover accrued installments under a New York decree. Relying on the Lynde case, the Connecticut court denied recognition upon a finding that the arrearages were subject to the discretion of the New York court. Sistare v. Sistare, 80 Conn. 1, 66 Attl. 772 (1907).

${ }^{12}$ This language has been interpreted to mean that even "vested" accruals are not entitled to full faith and credit where there has been a prior prospective modification by the F-1 court. See Paulin v. Paulin, 195 Ill. App. 350 (1915); 2 Beale, The Conflict of Laws 1393 (1935). The merits of such an interpretation appear questionable. Assuming that finality is requisite to full faith and credit, it is difficult to understand how a prior prospective modification could affect the finality of the accrued installments at the time of the F-2 proceeding if the installments were not susceptible to retrospective modification.

${ }^{13}$ Sistare v. Sistare, 218 U.S. 1, 16-17 (1909).

${ }^{14}$ This conclusion was supported by the restrictive test of retrospective modification propounded by the Court: "[E]very reasonable implication must be resorted to against the existence of such power [of retrospective modification] in the absence of clear language manifesting an intention to confer it." Id., at 22.

${ }^{15}$ Where the foreign decree is retrospectively modifiable most courts have refused all recognition, claiming the Sistare case as authority for this position. See cases collected in Decree for Alimony in Installments as within Full Faith and Credit Provisions, 157 A.L.R. 170 (1945).

${ }^{16}$ This assumption is open to serious question. "Neither the full faith and credit clause of the Constitution nor the Act of Congress implementing it says anything about final judgments or, for that matter, about any judgments. Both require that full faith and credit be given to 'judicial proceedings' without limitation as to finality." Mr. Justice Jackson concurring in Barber v. Barber, 323 U.S. 77, 87 (1944). Similarly, see Mr. Justice Rutledge, dissenting in part, in Griffin v. Griffin, 327 U.S. 220, 247 (1946), and Mr. Justice Frankfurter's and Mr. Justice Rutledge's concurring opinions in Halvey v. Halvey, 330 U.S. 610, 616-17, 620-21 (1947). 
which can be attached in F-1. The undesirability of this result has led a few courts to recognize retrospectively modifiable decrees on grounds of comity. ${ }^{17}$ Agreeing that they are not required to recognize such decrees under the Sistare rule, these courts have proceeded to state that the rule does not prevent recognition. Such comity recognition appears highly desirable, but since it rests with the discretion of the courts of each state, it does not appear to be a dependable solution to the recognition problem.

It is against this background that the Light case must be viewed. Justice Schaeffer, speaking for the Illinois court, recognized the Sistare rule and stated that the accrued installments were not entitled to full faith and credit if retrospectively modifiable in Missouri. The defendant contended that this limitation applied as Missouri would retrospectively modify the decree to conform to an agreement between the parties. ${ }^{18}$ The court did not deny this contention, but held instead that the arrearages were entitled to full faith and credit on the grounds that the lower court found no agreement and the defendant failed to properly appeal this finding.

Even had such an agreement been proven, it is doubtful that this would have been sufficient to deny full faith and credit under the rule of the Sistare case since the limitation set forth there applies in cases in which "the right to demand and receive such future alimony is discretionary with the court which rendered the decree. . . ."19 It appears that the Supreme Court was only concerned with such modifications as were within the power of the original court, and such retrospective modification as depends on an out-of-court agreement of the parties falls outside the bar of the Sistare decision, since the amount would not be subject to the discretion of the court. ${ }^{20}$

Since Missouri courts do not have the power to retrospestively modify their decrees, ${ }^{21}$ it would seem that the Light case is consistent, so far, with the Sistare rule. On the other hand, it might well be contended that the reasons of sound

${ }^{17}$ Worthley v. Worthley, 44 Cal.2d 465, 283 P.2d 19 (1955); Sorenson v. Spence, 65 S.D. 134, 272 N.W. 179 (1937); Bolton v. Bolton, 86 N.J.L. 69, 89 Atl. 1014 (S.Ct., 1914), aff'd on other grounds 86 N.J.L. 622, 92 Atl. 389 (1914), the Court of Errors and Appeals holding that the accruals were entitled to full faith and credit as they were not retrospectively modifiable. See Gough v. Gough, 101 Cal.App.2d 262, 255 P.2d 668 (1951). Cf. Holton v. Holton, 153 Minn. 346, 190 N.W. 542 (1922). Retrospectively modifiable arrearages were held entitled to full faith and credit where there had not been a previous retrospective modification.

${ }_{18}$ Maxey v. Maxey, 212 S.W.2d 810 (Mo.App., 1948); Meyers v. Meyers, 22 S.W.2d 853 (Mo.App., 1929).

${ }^{19}$ Sistare v. Sistare, 218 U.S. 1, 17 (1909). Similarly, the test of retrospective modifiability established on the Sistare case is phrased in terms of the "power" of the court. See note 14 supra.

${ }^{20}$ This distinction was made in Shilbey v. Shilbey, 181 Wash. 166, 42 P.2d 446 (1935). If an agreement to modify meets the requirements of an enforceable contract, retrospective modification would appear permissible irrespective of the accruals being "vested." But see Mosher v. Mosher, 25 Wash.2d 778, 172 P.2d 259 (1946), which suggests a different result in the case of support decrees as the rights of the children are involved.

21 Nelson v. Nelson, 282 Mo. 412, 221 S.W. 1066 (1920). 
public policy and of constitutional interpretation which led the Illinois court to hold that modifiable future installments are entitled to full faith and credit are equally applicable to modifiable arrearages. Viewed in this light, the Illinois decision constitutes a step away from the strict Sistare prohibition and towards mandatory recognition of retrospectively modifiable decrees.

Recognition, whether by full faith and credit or by comity, of W's substantive right to accrued installments may be worth little if she is limited to an action of debt, the classic means of enforcing a foreign money judgment.

Passages in both the early Barber opinion ${ }^{22}$ and the Lynde opinion ${ }^{23}$ have been construed to mean that full faith and credit does not purport to describe enforcement proceedings so that there is no compulsion on a state to make available to a foreign alimony decree the same enforcement proceedings accorded to a domestic decree. ${ }^{24}$ Thus, the beneficial equitable remedies of contempt, bond sequestration, and receivership may be unavailable to $W$ unless $F-2$ provides them by statute..$^{25} \mathrm{~A}$ growing number of states, however, have allowed equitable enforcement on grounds of comity. ${ }^{26}$ This has usually been coupled with prospective recognition and enforcement of future installments so that the foreign decree is treated as if it were a domestic one.

\section{II}

Recognition of future installments is closely associated with the problem of equitable enforcement. If W's only remedy in F-2 is an action at law, she must

22 "Alimony decreed to a wife in a divorce of separation from bed and board is as much a debt of record, until the decree has been recalled, as any other judgment for money is." 21 How. (U.S.) 582,595 (1859).

The phrase "debt of record" was adopted to signify that the equity decree was a judgment capable of supporting an action of debt. Instead it has been interpreted to mean that alimony constitutes such a debt, and that an action at law is an adequate remedy against the defaulting husband. See Jacobs, op. cit. supra note 2, at 270. Compare Lawrence v. Lawrence, $196 \mathrm{Ga} .204$, 26 S.E.2d 283 (1943), with Ostrander v. Ostrander, 190 Minn. 547, 252 N.W. 449 (1934).

23 "The provisions [of the foreign decree] for bond, sequestration, receiver and injunction being in the nature of execution, and not of judgment, could have no extra-territorial operation; but the action of the courts of New York in these respects depended on the local statutes and practices in the state. ..."181 U.S. 183, 187 (1901). Cf. M'Elmoyle v. Cohen, 13 Pet. (U.S.) 312 (1839).

24 Equitable enforcement has generally been denied on one of three grounds: (1) that it is not required by the Full Faith and Credit Clause, e.g., Scholla v. Scholla, 201 F.2d 211 (App. D.C., 1953), cert. denied 345 U.S. 966 (1953); (2) that W has an adequate remedy at law, e.g., Weidman v. Weidman, 274 Mass. 118, 174 N.E. 206 (1931); and (3) that equitable enforcement of alimony decrees is solely statutory, and the local statute applies only to domestic decrees, e.g., Mayer v. Mayer, 154 Mich. 386, 117 N.W. 890 (1908); Page v. Page, 189 Mass. 85, 75 N.E. 92 (1905).

${ }_{25}$ See 6A Mass. Ann. L. (1955) c. 208, §35; 2A N.J. Stat. Ann. (1952) §34-23; 6A N.Y. Civ. Prac. Act Ann. (Gilbert-Bliss, 1944) $\$ \$ 1171-72$.

${ }^{26}$ E.g., Cummings v. Cummings, 97 Cal.App. 144, 275 Pac. 245 (1929); McDuffie v. McDuffie, 155 Fla. 63, 19 So.2d 511 (1944); McCabe v. McCabe, 210 Md. 308, 123 A.2d 447 (1956); Fanchier v. Gammill, 148 Miss. 723, 114 So. 813 (1927); Cousineau v. Cousineau, 155 Ore. 184, 63 P.2d 897 (1936). For the Illinois situation prior to the Light decision see note 29 infra. 
wait until the installments have accrued. Such a procedure, however, seriously weakens the efficacy of the decree. If $\mathrm{W}$ must bring successive actions at law, litigation expenses may severely curtail the value of her F-2 judgment. She may have to wait until sufficient installments have accrued in order to make litigation economically feasible. ${ }^{27}$ This seems to be antithetical to the idea of alimony installments providing $W$ with a continuing maintainance. Equitable relief with respect to accrued installments only, though increasing the probability that $W$ will be able to achieve satisfaction, does not solve the problem as she will still be required to bring successive suits. The answer appears to lie in the recognition and enforcement of future payments by "establishing" the F-1 decree as the decree of the F-2 tribunal and enforcing it by the same sanctions available to one obtaining a domestic decree.

States which have claimed strict adherence to the Sistare doctrine have generally refused prospective recognition. ${ }^{28}$ But an increasing number have allowed prospective recognition and enforcement on grounds of comity. ${ }^{29}$ These decisions have recognized that the obligation to pay alimony is materially different from the ordinary money judgment, ${ }^{30}$ and that the enforcement procedure for foreign money judgments is inadequate in the case of alimony decrees. They recognize

${ }^{27}$ See Scholla v. Scholla, 201 F.2d 211, 214 (App.D.C., 1953) (dissenting opinion), cert. denied 345 U.S. 966 (1953); Jacobs, op. cit. supra note 2, at 265-66.

${ }^{28}$ Where equitable relief has been held unavailable for enforcement of accrued installments, it has also been denied for prospective installments. See note 24 supra. However, the contention that W's remedy at law is adequate, at best questionable in the case of accruals, seems untenable where future payments are involved.

In German v. German, 122 Conn. 155; 188 Atl. 429 (1936), the anomalous result of granting equitable enforcement to overdue payments, while denying it to prospective installments, was reached. This appears to be the lone case in which the two situations were not treated similarly. The Connecticut court relied for this result on its prior determination in the Sistare case where it dealt only with accrued installments. Sistare v. Sistare, 80 Conn. 1, 66 Atl. 772 (1907), rev'd 218 U.S. 1 (1909).

${ }^{29}$ The leading case is Fanchier v. Gammill, 148 Miss. 723, 114 So. 813 (1927). Accord: Cummings v. Cummings, 97 Cal.App. 144, 275 Pac. 245 (1929); Sackler v. Sackler, 47 So.2d 292 (Fla., 1950); McCabe v. McCabe, 210 Md. 308, 123 A.2d 447 (1956); Ostrander v. Ostrander, 190 Minn. 547, 252 N.W. 449 (1934); Johnson v. Johnson, 194 S.C. 115, 8 S.E.2d 351 (1940); Cousineau v. Cousineau, 155 Ore. 184, 63 P.2d 897 (1936); Sorenson v. Spence, 65 S.D. 134, 272 N.W. 179 (1937); Guerica v. Guerica, 239 S.W.2d 169 (Tex.Civ.App., 1951); Mckeel v. Mckeel, 185 Va. 108, 37 S.E.2d 746 (1946); Shilbey v. Shilbey, 181 Wash. 166, 42 P.2d 446 (1935).

Prior to the Light decision the availability of equitable enforcement of foreign alimony decrees was doubtful in Illinois. In Rule v. Rule, 313 Ill.App. 108, 39 N.E.2d 379 (1942), equitable enforcement was upheld. But in Tailby v. Tailby, 342 Ill.App. 664, 97 N.E.2d 611 (1951), it was denied, the court relying on Clubb v. Clubb, 402 Ill. 390, 84 N.E.2d 366 (1949), where equitable enforcement was denied to the decree of a foreign country. The Tailby case appears to have been overruled, however, in Roberts v. Roberts, 11 Ill.App.2d 86, 136 N.E.2d 590 (1956), where the court returned to the Rule case. But prior to the Light decision, the Clubb case constituted the only statement by the Illinois Supreme Court on the availability of equitable enforcement.

${ }^{30}$ In other situations this difference has been legislatively or judicially noticed. A discharge in bankruptcy does not release $H$ from his alimony obligation. 52 Stat. 851 (1938); 11 U.S.C.A. $\$ 35(2)$ (1953); Audubon v. Shufeldt, 181 U.S. 575 (1901). Generally, alimony decrees may be 
also that H's obligation should not be extinguished or materially diminished solely by reason of his having left F-1. Though achieving the desired practical result of prospective recognition and enforcement, comity, since at the discretion of each state, fails to afford a dependable remedy for $W$.

The light case offers a solution. Stating that although there were "indications" in the leading cases that prospectively modifiable alimony decrees were not entitled to full faith and credit there were also "intimations" to the contrary in the same cases, Justice Schaeffer considered the matter to be an open question. Considerations of policy, the language of the Full Faith and Credit Clause ${ }^{31}$ and the practicality of the blueprint for foreign modification advanced in Worthley v. Worthley ${ }^{32}$ led him to conclude that the Missouri decree was entitled to full faith and credit as to future installments even though subject to prospective modification. While the result reached appears highly desirable it would seem that the matter is not so open as the Light decision indicates in view of the precedent of the Lynde case. ${ }^{33}$

With respect to future installments the Lynde case was not qualified by the Sistare decision, which dealt only with accrued installments. But if both cases are considered together, the Sistare case may be said to stand, by implication, for the proposition that modifiable future installments are not entitled to full faith and credit. The contention underlying both cases appears to be that if a portion of a decree is subject to modification, that portion is not entitled to full faith and credit as it lacks the alleged requisite finality. Such a view would seem to be prompted by a belief that $\mathrm{F}-1$ modification subsequent to $\mathrm{F}-2$ recognition and enforcement would result in chaos and confusion between the courts of F-1, F-2 and any third state which might subsequently serve as a forum for the litigation. It would follow that such a result could be avoided only by requiring nonmodifiability or "finality" of the F-1 decree as a prerequisite to foreign enforcement. ${ }^{34}$ If such a belief underlies the Sistare opinion, it would apply not only to

enforced by imprisonment for contempt, a remedy unavailable in the case of an ordinary money judgment or decree. See Chafee and Re, Cases and Materials on Equity 47 n.37(2) (4th ed., 1958).

${ }^{31}$ See Mr. Justice Jackson's concurring opinion in Barber v. Barber, 323 U.S. 77,87 (1944), at note 16 supra.

3244 Cal.2d 465, 283 P.2d 19 (1955). See discussion at 143 infra.

33 "The provision of the payment of alimony in the future was subject to the discretion of the Court of Chancery of New Jersey, which might at any time alter it, and was not a final judgement for a fixed sum." Lynde v. Lynde, 181 U.S. 183 (1902). See note 10 supra.

34 The alternative is to view finality as a technical requirement of full faith and credit. Such a view is highly questionable, as the contention that finality of amount is necessary to entitle a judgment to full faith and credit is not apparent from the language of the Constitution. See note 18 supra.

With respect to judgments, full faith and credit requires that a judgment be given the same conclusive effect in F-2 as it has in F-1. See 2 Story, Commentaries on the Constitution of the United States 187 (3d ed., 1858). Cf. Hampton v. M'Connell, 3 Wheat. (U.S.) 234 (1818); Mills v. Duryee, 7 Cranch (U.S.) 481 (1813). One of the first expressions of the finality require- 
modifiable accruals, but also to modifiable future installments. A practical plan for foreign modification, however, would allay the fears which may have engendered the finality limitation.

\section{III}

Recognition and enforcement of modifiable foreign alimony decrees, whether on grounds of full faith and credit or comity, raise several questions: (1) may F-2 modify a foreign decree or is the power restricted to the F-1 court; (2) are the limits of modification to be set by the law of F-1 or F-2; (3) whose law is to determine the grounds for modification and whether there has been a change in circumstances sufficient to justify modification; and (4) what will be the effect of F-2 modification on subsequent litigation on the decree in F-1 or a third state?

The Light decision suggests that modifiable decrees be treated according to the plan set forth by the California Supreme Court in Worthley v. Worthley. ${ }^{35}$ Five propositions make up this plan: (1) in a proceeding to enforce a foreign modifiable decree, where $\mathrm{F}-2$ has personal jurisdiction over both parties, it not only may, but it should afford an opportunity for the litigation of the question of modification; (2) F-1 law is to determine the limits of modification; (3) F-1 law is also to determine the grounds for modification; (4) where F-2 has determined the issue of retrospective modification of accrued installments, the judgment for a liquidated sum is final and entitled to full faith and credit in all other states; and (5) issues determined with respect to prospective modification will be res judicata so long as the circumstances of the parties remain unchanged.$^{36}$

Where the F-1 court renders a modifiable decree it retains jurisdiction over

ment acknowledged the difference between "conclusiveness" and "finality" in stating that "[ $t]$ he provision of the Federal Constitution, which requires that full faith and credit shall be given to the judicial proceedings of another state, in my opinion, should be deemed to relate to judgments, or decrees, which not only are conclusive on the jurisdiction where rendered, but which are final in their nature." Lynde v. Lynde, 162 N.Y. 405, 418, 56 N.E. 979, 983 (1900), aff'd 181 U.S. 183 (1901).

A modifiable alimony decree, though not final, constitutes a conclusive determination of H's obligation, provided the circumstances of the parties remain unchanged. Judicial action can legitimately affect $\mathrm{H}^{\prime} \mathrm{s}$ obligation, once determined, only where the status quo has been changed by acts of the parties or other agencies, e.g., tax changes or a major change in the cost of living; the F-1 decree can not be modified unless such a change has occurred, and, therefore, may be viewed as conclusive. It has been pointed out that finality-of-judgments requirements in conflict-of-laws situations are not rules of automatic application but depend instead on the particular circumstances. The Finality of Judgments in the Conflict of Laws, 41 Col. L. Rev. 878 (1941). Therefore, it may be suggested that "finality" as distinct from "conclusiveness" has no proper bearing on the recognition of modifiable alimony decrees.

${ }^{35} 44$ Cal.2d 465, 283 P.2d 19 (1955).

${ }^{36}$ Though the Worthley case dealt with comity recognition, the modification plan will apply equally well to a decree recognized under the Full Faith and Credit Clause. Thus, under the Uniform Enforcement of Foreign Judgments Act, if personal jurisdiction is secured over H subsequent to W's petition to register the foreign decree, $\mathrm{H}$ would be permitted to present such matters pertaining to modification as would be permitted in F-1. 
the subject matter so as to facilitate subsequent modification. This concept of "continuing jurisdiction" has resulted in F-2's refusal to modify a foreign decree on the grounds that such "jurisdiction" is exclusive, and full faith and credit forbids modification. ${ }^{37}$ Rejected in a few recent decisions, ${ }^{38}$ this contention appears to be without merit. First, accepting the applicability of "continuing jurisdiction" in the foreign enforcement situation, the conclusion that the F-1 jurisdiction is exclusive does not follow from its being "continuous." Second, it may be contended that "continuing jurisdiction" is not applicable to the foreign enforcement situation since its function is solely to facilitate domestic modification. ${ }^{39}$ Thus, F-2 should not be prevented from modifying an F-1 decree due to F-1's "retention of jurisdiction."

Though F-2 may modify, the limits of such modification should be determined by F-1 law. A difference between F-1 and F-2 law is likely to occur only with respect to retrospective modification since prospective modification will generally be permissible in both states..$^{40}$ Full faith and credit does not presently compel F-2 to litigate the issue of modification where F-1 law provides for modification but F-2 law does not. There appears, however, to be no reason why F-2 should not so modify. A dominant consideration in denying retrospective modification to domestic decrees is a desire to bring arrearages under such decrees within the protection of the Full Faith and Credit Clause. ${ }^{41}$ Where F-2 is

${ }^{37}$ Barns v. Barns, 9 Cal.App.2d 427, 50 P.2d 463 (1935); Goldberg v. Mayer, 243 App.Div. 477, 277 N.Y.Supp. 799 (1935), aff'd 270 N.Y. 660, 1 N.E.2d 986 (1936); Little v. Little, 146 Misc. 231, 262 N.Y.Supp. 654 (S.Ct., 1932). See Paulin v. Paulin, 195 III.App. 350 (1915). Cf. Yarborough v. Yarborough, 290 U.S. 202 (1933) (non-modifiable support settlements).

${ }^{38}$ Halvey v. Halvey, 330 U.S. 610 (1947). Dealing with a modifable custody decree, the Court stated that "so far as the Full Faith and Credit Clause is concerned, what Florida could do in modifying the decree, New York may do. ... [I]t is clear that the State of the forum has at least as much leeway to disregard the judgment, to qualify it, or to depart from it as does the State where it was rendered." Id., at 614-15. For subsequent applications of this reasoning to alimony decrees see, Anonymous v. Anonymous, 204 Misc. 656, 123 N.Y.S.2d 196 (Dom.Rel.Ct., 1953), aff'd sub nom. Barclay v. Marston, 283 App.Div. 659, 127 N.Y.S.2d 843 (1954); Robison v. Robison, 9 N.J. 288, 88 A.2d 202 (1952); Setzer v. Setzer, 251 Wis. 234, 29 N.W.2d 62 (1947).

The practical effect of modification has also been achieved where notions of "continuing jurisdiction" in the rendering state have compelled the court of the forum to deny the fact that it was undertaking modification. Thus, a few courts have spoken in terms of their decree "superseding" rather than modifying the F-1 decree. Lopez v. Avery, 66 So.2d 689 (Fla., 1953); Durfee v. Durfee, 293 Mass. 472,200 N.E. 395 (1936). Cf. Johnson v. Johnson, 196 S.C. 474, 13 S.E.2d 593 (1941). After stating it could not modify a foreign decree, the court decreased payments by granting prospective enforcement of only part of the installments decreed by F-1.

${ }^{39}$ See Interstate Recognition of Alimony Decrees, 41 Calif. L. Rev. 692, 710 (1953).

${ }^{40} 2$ Nelson, Divorce and Annulment $\$ 17.01$ (2d ed., 1945). For a discussion of the various positions respecting retrospective modification see, Retrospective Modification of, or Refusal to Enforce, Decrees for Alimony, Separate Maintenance or Support, 6 A.L.R.2d 1277 (1949).

${ }^{41}$ Though allowed in only a minority of states, retrospective modification may be a desirable social policy. See Nelson, op. cit. supra note 40, at \$17.05; Retrospective Modification of Alimony Decrees: A Proposed Innovation for Illinois, 22 U. of Chi. L. Rev. 246 (1954). It can 
dealing with a foreign decree, retrospective modification does not conflict with this policy. Nor is any burden placed on F-2's judicial machinery as the procedure is no more complex for litigating the issue of retrospective modification than it is in the case of prospective modification which $\mathrm{F}-2$ probably allows for domestic decrees. Thus, if F-2 enforces a modifiable decree it should permit modification, retrospective or prospective, upon proof of changed circumstances, rather than requiring the parties to return to F-1, a highly impractical solution. ${ }^{42}$ Conversely, if $F-1$ decrees are not modifiable, full faith and credit prevents F-2 modification. ${ }^{43}$

Though F-1 law should govern the limits of modification, it does not follow that it must govern the grounds for modification. Though generally permitted where changed circumstances have rendered the previously determined payments inequitable, ${ }^{44}$ modification policy differs from state to state. Thus F-2 may find itself confronted with a choice of law situation. Where F-1 and F-2 law differ as to whether a particular change in the parties' circumstances constitutes grounds for modification, there is reflected a difference in policy as to whether $\mathrm{W}$ or $\mathrm{H}$ is to be protected in view of the changed situation. Policies protecting $W$ will result in increased payments at her petition and proof of change or in denial of reduction or cancellation at H's motion. Conversely, policies protecting $\mathrm{H}$ result in reduction or cancellation of his obligation or in denial of increases.

Foreign recognition and enforcement are usually requested where one party no longer resides in F-1. Thus, with respect to modification, four interesting situations are possible: $:^{45}$

$\begin{array}{ccccc}\text { Case } & \begin{array}{c}\text { H's } \\ \text { Residence }\end{array} & \begin{array}{c}\text { W's } \\ \text { Residence }\end{array} & \begin{array}{c}\text { F-1 Policy } \\ \text { Protects }\end{array} & \begin{array}{c}\text { F-2 Policy } \\ \text { Protects }\end{array} \\ 1 & \text { F-1 } & \text { F-2 } & \text { H } & \text { W } \\ 2 & \text { F-2 } & \text { F-1 } & \text { H } & \text { W } \\ 3 & \text { F-1 } & \text { F-2 } & \text { W } & \text { H } \\ 4 & \text { F-2 } & \text { F-1 } & \text { W } & \text { H }\end{array}$

not be doubted, however, that one effect of the Sistare decision has been to promote a reluctance in state courts and legislatures towards providing retrospective modification of domestic decrees. See Nelson v. Nelson, 282 Mo. 412, 226 S.W. 1066 (1920).

42 But see Sackler v. Sackler, 47 So.2d 292 (Fla., 1950). The court refused to recognize and enforce retrospectively modifiable arrearages which had not been reduced to a final judgment in F-1 on the grounds that Florida did not allow retrospective modification, of domestic decrees. At the same time the court granted recognition and enforcement to prospectively modifiable future installments.

${ }^{43}$ Cf. Yarborough v. Yarborough, 290 U.S. 202 (1933).

${ }^{14}$ See Nelson, op. cit. supra note 40 , at $\$ 17.07-17.20$ for a discussion of changed circumstances sufficient for modification.

${ }^{15}$ The choice of F-1 and F-2 as the residences of the parties is used for simplicity. Where one party resides in a third state rather than F-1, the law of that state should be of concern rather than the law of F-1. That the original decree was rendered in F-1 should not be sufficient to justify the choice of F-1 law where neither party is a resident; and F-1, consequently, has no interest in the litigation. Where neither state has an interest in the litigation because neither party is a resident, a dismissal on grounds of forum non conveniens may be in order. This accounts for the possibilities other than those considered in the text. 
In each case the determination of the applicable modification law should depend on the economic and social policies of F-1 and F-2 and on the interests of the states in having their policies applied to that case. ${ }^{46}$ In case 1 both F-1 and F-2 have an interest in the application of their policies. F-1 protects husbands, and as $\mathrm{H}$ is a resident his economic well-being is a matter of $\mathrm{F}-1$ concern. Similarly, F-2 policy protects wives; $W$ is a resident; and, thus, $F-2$ has an interest. Neither F-1 nor F-2 has an interest in case 2 as neither party resides in the state which is primarily concerned with his (her) economic protection with respect to the particular change in circumstances upon which modification is requested. Cases 3 and 4 present the converse situations as here the modification policies are reversed. Thus, in cases 1 and 4 both states have an interest in the issue of modification; whereas in cases 2 and 3 neither state is interested.

Arguably, F-2 law should apply in both situations. Where both states have an interest in the outcome of the litigation (cases 1 and 4) a court should forego the foreign policy in the advancement of the domestic policy. ${ }^{47}$ Where neither state has an interest (cases 2 and 3 ) it may be contended that a court should apply its own law on grounds of expertise and because there is no reason to apply the foreign law..$^{48} \mathrm{And}$, clearly, where both parties reside in F-2, its modification policy should prevail as it is the only interested state.

However, the effect of choice of law as to the grounds for modification must be considered with respect to subsequent litigation in F-1 or a third state which may become a subsequent forum. If the law of the forum is to determine the grounds for modification, where one party resides in the forum and the other in the state rendering the original decree, the applicable law will vary according to choice of forum. Due to the modifiability of the decree, litigation may not end with the F-2 proceeding. If modification policy is determined solely by the choice of forum, each subsequent forum will be able to modify the decree in accord with its domestic determination of changed circumstances. ${ }^{49}$ Since res judicata

${ }^{46}$ For a discussion of this approach to the problem of conflict of laws, see, Currie, On the Displacement of the Law of the Forum, 58 Col. L. Rev. 964 (1958); Currie, Survival of Actions: Adjudication versus Automation in the Conflict of Laws, 10 Stan. L. Rev. 205 (1958); Currie, Married Women's Contracts: A Study in Conflict-of-Laws Method, 25 U. of Chi. L. Rev. 227 (1958). Compare the suggestions regarding modification in Scoles, Enforcement of Foreign "Non-Final" Alimony and Support Orders, 53 Col. L. Rev. 817, 823 (1953).

47 "The sensible and clearly constitutional thing for any court to do, confronted with a true conflict of interests, is to apply its own law." Currie, Married Women's Contracts: A Study in Conflict-of-Laws Method, 25 U. of Chi. L. Rev. 227 (1958).

\footnotetext{
${ }^{48}$ Under this analysis F-1 law would properly be applied only if F-1 had a policy and an interest and F-2 did not. This situation does not arise in the present context, however. See 148 supra.

${ }^{49}$ For example, F-2 might decrease the payments upon its determination of changed circumstances in accord with its own law. If $\mathrm{F}-1$ subsequently obtained personal jurisdiction over $\mathrm{H}$, it could re-establish the original amount of the obligation according to its law. Such a situation might continue indefinitely.
} 
would not be applicable in such a situation, ${ }^{50}$ the confusion which would result from each subsequent forum's ability to disregard prior determinations as to modification and to vary the decree by the application of its own law seems to be too high a price to pay for the advancement of domestic interests or for expertise..$^{51}$

A choice of law based on the specific interests (or lack of interests) of the states involved may have to give way to a general policy favoring state to state uniformity of result. ${ }^{22}$ Where neither state has an interest there is no reason why this general policy should not determine the choice of law. ${ }^{53}$ But where both states have an interest, subordination of the forum's interest is difficult to justify. However, along with its specific policy of protecting one of the parties with respect to the particular change in circumstances involved it may be assumed that a state has a general policy favoring the speedy and effective recognition and enforcement of H's obligation of support, not only within that state, but within any state in which subsequent litigation may arise. Uniformity of result is desirable for the furtherance of such a policy. Thus, it may be suggested that even at the sacrifice of the specific domestic policy the general policy should prevail.

Two choices of law may be suggested, in furtherance of such a policy. The choice of F-1 law would have the advantage of providing a fixed standard at the time of the rendition of the original decree and would, therefore, promote the greatest uniformity. But where neither party resides in F-1 such a choice might result in the application of a policy totally unrelated to the interests involved in the litigation. An alternative would be a determination that the law of the state of the residence of one of the parties should control. The choice of which party's residence would be largely immaterial as long as consistently followed within the particular case. However, the choice of W's residence might have the advantage of preventing a defaulting runaway husband from choosing a residence solely on the basis of a favorable modification policy. Such a determination would have the advantage of being connected with the interests involved in the litigation even though uniformity would be somewhat sacrificed where the operative party

${ }^{50}$ Res judicata would apply only if the legally cognizable circumstances remained unchanged. But if the law of each forum is to determine what changes justify modification, a change in forum and resulting change of law would necessitate a different judicial determination as to the relevant circumstances of the parties.

${ }^{51}$ See note 49 supra.

52 See Currie, Married Women's Contracts: A Study in Conflict-of-Laws Method, 25 U. of Chi. L. Rev. 227, 246 (1958), where Professor Currie criticizes the uniformity-of-result justification of the traditional approach to conflict-of-laws problems. As these criticisms seem directed at the desire for uniformity of result if a particular case were to arise de novo in different jurisdictions, it is questionable whether this criticism applies to the desire for uniformity where dealing with subsequenl litigation in a particular case.

${ }^{53}$ See Currie, Survival of Actions: Adjudication versus Automation in the Conflict of Laws, 10 Stan. L. Rev. 205, 234 n. 86 (1958). 
has changed residence. But since the forum's law will apply where both parties reside there, ${ }^{54}$ a slight sacrifice in uniformity has already been admitted.

The Worthley plan states that F-1 law is to determine the grounds for modification, apparently based upon the idea that due process requires that $\mathrm{H}$ be allowed to present defenses in F-2 which would have been available in F-1.55 This interpretation of due process is open to serious criticism. ${ }^{56}$ In the light of the prior discussion it may be suggested that the law governing modification should be that of W's residence in all cases. ${ }^{57}$ Thus the interests of the state, or states, in which the parties reside will in large measure be followed and a high degree of uniformity will be achieved.

As to retrospective modification, the Worthley plan provides that, after the issue of modification has been litigated and judgment entered for a liquidated sum, the installments are no longer subject to modification and are entitled to full faith and credit in all other states. ${ }^{58}$ As to modification of installments accrued subsequent to the F-2 decree and of future installments, the issues determined in the F-2 proceeding will be res judicata ${ }^{59}$ as long as the circumstances of the parties remain unchanged. Following the holding of the Light case, that prospectively modifiable decrees are entitled to full faith and credit as to future

54 The situation in which both parties reside in F-2 may become a more frequently recurring one in view of a present predilection to secure a foreign divorce under more "liberal" laws where economically feasible. Thus, Nevada may increasingly figure in as F-1 where the only contact the parties have had with the state was the divorce litigation. See, e.g., McCabe v. McCabe, 210 Md. 308, 123 A.2d 447 (1956).

${ }_{55}$ The Worthley case relied on Griffin v. Griffin, 327 U.S. 220 (1946), for this proposition. The Supreme Court held that an action on a New York judgment for accrued alimony was not entitled to full faith and credit since $H$ had not been notified of the New York proceeding, and, thus, he was prevented from presenting defenses, including retrospective modification, which under New York law might have been available to him. The Court proceeded to state that upon remand $W$ might bring an action to enforce the original decree, but $H$ should be allowed to present any defenses he might have. Though not stated, the implication seems to be that these were to be defenses available under New York law. No mention of due process was made, however, regarding the subsequent F-2 proceeding. Though a majority of the Court held that due process required that $H$ be given notice of the $F-1$ proceeding regarding the accrued alimony, it does not follow that due process required the use of F-1 law in the F-2 proceeding. Thus, the California Court's determination is open to question.

${ }^{56}$ See Currie, The Constitution and the Choice of Law: Governmental Interests and the Judicial Function, 26 U. of Chi. L. Rev. 1 (1958).

${ }^{57}$ In the typical situation $H$ has left F-1, W remaining. Thus, the choice of the law of W's residence would usually result in the application of F-1 law-for very different reasons, however, than those suggested by the Worthley decision.

58 This procedure is consistent with that followed in those states allowing retrospective modification whereby $W$ may petition for the accrued installments to be entered as a judgment for a liquidated sum no longer susceptible to retrospective modification. See, e.g., N.Y. Civ. Prac. Act Ann. (Gilbert-Bliss, 1944) \$1170. For the relation of such judgments to the Sistare rule see Barber v. Barber, 323 U.S. 77 (1944). As to the requirement of adequate notice of subsequent proceedings resulting in such a judgment see, Griffin v. Griffin, 327 U.S. 220 (1946).

59 Having established that the law governing the grounds for modification is to be that of W's residence, res judicata is now applicable since only those changed circumstances cognizable under the law of her residence will be sufficient to open the question of modification in subsequent proceedings. Compare note $\mathbf{5 1}$ supra. 
installments, recognition of the F-2 decree would be mandatory on all states, including F-1. And if the Light case may be liberally interpreted so as to require full faith and credit to retrospectively modifiable decrees, ${ }^{60}$ recognition of installments accrued subsequent to the $F-2$ proceeding would also be mandatory in subsequent litigation.

The Worthley plan, with appropriate changes regarding the determination of the law governing the grounds for modification, offers a practical means of resolving the problems of foreign modification. Since these problems may well have formed the underlying considerations which have resulted in the "finality" requirement, the adoption of a practical plan for foreign modification would constitute a strong step towards mandatory recognition and enforcement of foreign modifiable alimony decrees.

\section{TV}

The difficulties presently encountered in attempts at direct enforcement suggest that a two-state proceeding under the Uniform Reciprocal Enforcement of Support Act ${ }^{61}$ may provide a suitable alternative procedure. While the Act is designed primarily for the initial imposition of support duties, ${ }^{62}$ it can also be used to enforce support duties obtained outside the Act..$^{63}$ Where the Act is used to impose a support duty, F-1 (the initiating state) determines whether W's petition sets forth facts upon which a duty of support may be predicated. It then forwards the petition to F-2 (the responding state) which determines and fixes the amount of the obligation. Where the Act is used to enforce an existing decree, F-2 determines only the amount to be enforced. ${ }^{64}$ Since the decree functions only as a determination of the existence of a support duty, it is immaterial that it may be subject to modification in F-1.

F-2 is not bound by the F-1 decree but may increase or decrease the obligation according to its own law ${ }^{65}$ as opposed to modification in a direct preceeding. In the latter, F-2 law would necessarily affect the extent of the obligation only where both parties reside there, a situation in which a two-state proceeding is unnecessary. The implication of the provision that F-2 law should determine the

${ }^{60}$ See discussion at 139 supra.

${ }^{61} 9$ C U.L.A. 1 (1957); Ill. Rev. Stat. (1957) c. 68, \$50. The Illinois Act differs in a number of respects from the original Uniform Act. While the Uniform Act applies only to inter-state proceedings, the Illinois Act applies to intra-state proceedings also. The Uniform Act, or similar legislation, has been enacted in every state.

62 See Commissioners' Prefatory Note to the 1950 Act, 9C U.L.A. 3 (1957).

63 " 'Duty of support' includes any duty of support imposed or imposable by law, or by any court order, decree or judgment, whether interlocutory or final, whether incidental to a proceeding for divorce, judicial [legal] separation, separate maintenance or otherwise." Uniform Reciprocal Enforcement of Support Act (1957) §2(6), 9C U.L.A. 16 (1957).

"S See Thompson v. Thompson, 93 So.2d 90 (Fla., 1957). For other applications of the Act to the enforcement of alimony decrees, see, Gohdes v. Gohdes, 134 Cal.App.2d 819, 286 P.2d 539 (1955); Whittlesey v. Bellah, 130 Cal.App.2d 182, 278 P.2d 511 (1955); Smith v. Smith, 125 Cal.App.2d 154, 270 P.2d 613 (1954).

${ }^{65}$ Uniform Reciprocal Enforcement of Support Act (1957) §27, 9C U.L.A. 27 (1957). For a criticism of this provision see Ehrenzweig, Interstate Recognition of Support Duties, 42 Calif. L. Rev. 382 (1954). 
duty of support and of the provision that no order made by F-2 shall supersede any previous order of suppor ${ }^{66}$ is not only that $\mathrm{H}$ and $\mathrm{W}$ will have to relitigate the question of the extent of the support duty in any subsequent forum, but also that the F-2 order will not constitute a modification of the decree in any subsequent direct proceeding. ${ }^{67}$ Direct enforcement does not present these difficulties; but if it is limited to "final" decrees, a two-state proceeding under the Uniform Act may be W's only remedy. The Act does have the advantages, however, of providing $W$ with a reasonably inexpensive procedure for enforcing her right and entitling her to the equitable enforcement procedures. ${ }^{68}$

Because of the defects in the determination of support duties, a direct enforcement proceeding appears preferable. A two-state proceeding would probably be used only where $W$ was unable to afford the expense of direct enforcement of the decree via the full-faith-and-credit approach of the Light decision. This should be particularly true in a state, such as Illinois, which has adopted the Uniform Enforcement of Foreign Judgments Act, so that W will not only be assured of complete substantive recognition of the foreign decree but of the necessary equitable enforcement procedures as well. Therefore, mandatory direct recognition and enforcement of foreign modifiable alimony decrees as suggested in the Light decision's determination that such decrees are entitled to full faith and credit, coupled with equitable enforcement and the amended plans for foreign modification suggested in the Worthley case, offer a necessary and effective step towards a practical solution of the problems of recognition, enforcement, and modification of foreign alimony decrees which have troubled the courts since the Lynde and Sistare decisions.

${ }^{66}$ Uniform Reciprocal Enforcement of Support Act (1957) \$27, 9C U.L.A. 69 (1957).

${ }^{67}$ Despain v. Despain, 78 Idaho 185, 300 P.2d 500 (1956). An order entered in California under the Uniform Act was held not to constitute a modification of the original decree. Such a result follows from Section 27 of the Act. The effect of this provision is that $\mathrm{H}$, who has fulfilled his obligations according to the order entered in the enforcement proceeding, may subsequently, in a direct proceeding, find he is still liable for accruals under the decree. Similarly, a support order entered in the responding state has been held not to bar subsequent direct action on the original decree. Stubblefield v. Stubblefield, 272 S.W.2d 633 (Tex.Civ.App., 1954).

${ }^{68}$ Uniform Reciprocal Enforcement of Support Act (1957) §22, 9C U.L.A. 60 (1957).

\section{FEATHERBEDDING AND THE FEDERAL ANTI- RACKETEERING ACT}

Featherbedding describes a great variety of union attempts to preserve the jobs of its members by requiring that work be done by ineficient methods, by requiring employers to have their employees perform services which are unwanted or by forcing employers to hire employees whom they do not want. ${ }^{1}$ The

${ }^{1}$ See Slichter, Union Policies and Industrial Management 166 (1941). Featherbedding is usually a response to technological change. See generally Aaron, Governmental Restraints on Featherbedding, 5 Stan. L. Rev. 680 (1953); Countryman, The Organized Musicians, 16 U. of Chi. L. Rev. 56, 77-85 (1948). 